ROCZNIKI NAUK SPOŁECZNYCH

Tom 11(47), numer 2 - 2019

DOI: http://dx.doi.org/10.18290/rns.2019.47.2-2

MARTA MORAWSKA

\title{
HOW DOES FACEBOOK MAKE US UNHAPPY? A RESEARCH REVIEW
}

\section{INTRODUCTION}

Ever since people started using computers, researchers, thinkers, and technologists have tried to examine its possible impact on society. ${ }^{1}$ Many scholars, technologists, and social critics believed that the changes introduced by the computer use and the Internet (in particular), are transforming economic and social life. ${ }^{2}$ Consequently, these transformations have shown to influence peoples' health and well-being on many levels of investigation. ${ }^{3}$

Face-to-face interactions with other people are known to be beneficial to mental health and life satisfaction by fulfilling basic human social and

Marta MorawsKa, a PhD candidate at Poznań University of Economics; address for correspondence: Al. Niepodległości 10,61-875 Poznań, Poland; e-mail: mmorawska7@outlook. com.

${ }^{1}$ See, for example, J. SHORT, The Social Psychology of Telecommunications (London: John Wiley \& Sons, 1976); D. Bell, The Coming of Post-Industrial Society: A Venture in Social Forecasting (New York: Basic Books, 1973).

${ }^{2}$ See, for example, R. H. Anderson, T. K. Bikson, S. A. LAw, and B. M. Mitchell, eds., Universal Access to E-Mail: Feasibility and Societal Implications (Santa Monica, CA: Rand Corporation, 1995); J. K. King and K. L. KRAEMER, "Computer-Based Models for Policy-Making: Uses and Impacts in the U.S. Federal Government," in Information Systems in the Political World, ed. K. V. Andersen (Amsterdam: IOS Press, 1995), 129-46.

${ }^{3}$ M. BurKe and R. KrAut. "Using Facebook After Losing a Job: Differential Benefits of Strong and Weak Ties" (paper presented at the SIGCHI Conference on Human Factors in Computing Systems, April 2010), https://doi.org/10.1145/2441776.2441936; E. N. STEINFIELD and C. LAMPE, "The Benefits of Facebook 'Friends': Social Capital and College Students' use of online social network sites," Journal of Computer-Mediated Communication 12, no. 4, 1143-68; R. KRAUT ET AL. "Internet Paradox: A Social Technology That Reduces Social Involvement and Psychological Well-Being?” American Psychologist 53, no. 9 (1998): 1017-31, doi:10.1037// 0003-066x.53.9.1017; P. SutClifFE ET AL., "Systematic Review of Communication Technologies to Promote Access and Engagement of Young People with Diabetes into Healthcare," BMC Endocrine Disorders 11, no. 1 (2011), doi:10.1186/1472-6823-11-1. 
relatedness needs and by elevating the sense of well-being. This is perhaps less true for socializing online. ${ }^{4}$ For a long time, studies on social networking and its effect on mental health and well-being have been controversial. ${ }^{5}$ Researchers examining Facebook influence on well-being use different concepts of well-being, which makes it difficult to compare their findings. ${ }^{6}$ Moreover, since Facebook serves many different purposes, ${ }^{7}$ treating its association to decreased well-being and depression by measuring "general use" is likely an oversimplification, resulting in an imprecise interpretation regarding the nature of this connection. ${ }^{8}$ Instead, it is suggested to shift focus to what processes cause certain effects in particular populations. ${ }^{9}$ For example, a passive Facebook behavior is a better predictor of envy and subsequent decrease in well-being than an active Facebook behavior is, highlighting the importance of differentiating between types of Facebook use. ${ }^{10}$ Another process is Facebook procrastination - the act of delaying tasks because of media multitasking enabled by Facebook's many functions pulling at users attention combined with large amounts of time spent on Facebook, prove to be an important predictor of depressive symptoms in users. ${ }^{11}$

Since the relationship between Facebook use and its influence on users' well-being is complicated and a lot is yet to be learned, the aim of this

\footnotetext{
${ }^{4}$ See, for example, Kraut et Al., Internet Paradox; B. Latané et AL., "Distance Matters: Physical Space and Social Impact," Personality and Social Psychology Bulletin 21, no. 8 (1995): 795-805. doi:10.1177/0146167295218002.

5 I. PANTIC, "Online Social Networking and Mental Health," Cyberpsychology, Behavior, and Social Networking 17, no. 10 (2014): 652-57, doi:10.1089/cyber.2014.0070.

${ }^{6}$ P. Verduyn eT AL., "Passive Facebook Usage Undermines Affective Well-Being: Experimental and Longitudinal Evidence," Journal of Experimental Psychology: General 144, no. 2 (2015): 480-88; X. Hu ET AL., "The Facebook Paradox: Effects of Facebooking on Individuals' Social Relationships and Psychological Well-Being," Frontiers in Psychology 8 (2017): 87.

${ }^{7}$ See R. E. Wilson, S. D. Gosling, and L. T. Graham, "A Review of Facebook Research in the Social Sciences," SAGE Journals 7, no. 3 (2012): 203-20.

${ }^{8}$ M. KAlPidOU, D. Costin, and J. Morris, "The Relationship between Facebook and the WellBeing of Undergraduate College Students," Cyberpsychology \& Behavior 14, no. 4 (2011): 183-89.

${ }^{9}$ P. M. Valkenburg and J. Peter, "Social Consequences of the Internet for Adolescents," Current Directions in Psychological Science 18, no. 1 (2011): 1-5.

${ }^{10}$ H. Krasnova ET AL., "Envy on Facebook: A Hidden Threat to Users' Life Satisfaction?" (paper presented at 11th International Conference on Wirtschaftsinformatik, Leipzig, Germany 2013, February 27-March 1, 2013), https:/www.researchgate.net/publication/256712913_Envy _on_Facebook_A_Hidden_Threat_to_Users'_Life_Satisfaction/link/559501ec08ae793d1379b742 /download; VerduYn ET AL., "Passive Facebook usage."

${ }^{11}$ L. D. Rosen, L. M Carrier, and N. A. Cheever, "Facebook and Texting Made Me Do It: Media-Induced Task-Switching While Studying," Computers in Human Behavior 29, no. 3 (2013): 948-58.
} 
review is to present the relation between Facebook use and the potentially detrimental effects on users' well-being, and explore the mechanisms that contribute to depression and other negative consequences on users' mental health.

To conduct the review, I have gathered empirical articles on Facebook use and detrimental effects on users' well-being, published in academic journals, or conference proceedings between 2004 and 2017. To be considered as relevant articles, the articles had to be focused on Facebook (but not necessarily only Facebook), published in peer-reviewed academic journals or conference proceedings and report empirical findings. By using search engines, such as ScienceDirect, Google Scholar, Directory of Open Access Journals, and Scopus, I generated a pool of 117 potentially relevant articles and then chose a smaller aggregation of papers regarded as significant based on the inclusion criteria listed above. After selecting the articles that met the criteria, I examined the many nuances and details of how Facebook use negatively affects users' well-being and identified major topic areas that systematically organize the structure of this review. Special attention was paid to feelings of envy induced by comparisons made on Facebook and Facebook procrastination.

\section{THE MECHANISMS CONTRIBUTING TO FACEBOOK DEPRESSION}

People do not join Facebook for the purpose of becoming depressed, yet mounting research supports the idea of "Facebook Depression." The concept was first introduced as a clinical report in the American Academy of Pediatrics (AAP) journal, detailing the possible detriments to mental health that are associated with using social networking systems (SNS). ${ }^{12}$ Since then "Facebook Depression" is a widely used notion and frequently appears in media headlines. ${ }^{13}$

To better elucidate the relationship between SNS use and its negative impact on users' psychological well-being, it is useful to look at early research related to Internet use and its effect on users' well-being. In that research, a meta-analysis of 43 studies found small but apparently detrimental effect

\footnotetext{
${ }^{12}$ G. S. O'KeEFFE and K. Clarke-PeArson, “The Impact of Social Media on Children, Adolescents, and Families," Pediatrics 127 (2011): 800-804, http://dx.doi.org/10.1542/peds.2011-0054.

${ }^{13}$ L. Guernsey, "A Cautionary Tale of Pediatricians, Parents, and Facebook," February 19, 2014, http://www.slate.com/blogs/future_tense/2014/02/19/facebook_depression_scare_offers_ a_cautionary_tale_of_pediatricians_parents.html?via=gdpr-consent.
} 
of Internet use on psychological well-being. ${ }^{14}$ Kraut et al. were among the first researchers to look at the effects of Internet on mental health and found that more time spent using the Internet related to feelings of depression and loneliness. This was theorized to occur due to a displacement of "strong ties," such as time spent with the family and reduction of individuals' social circles, even when the main use of the Internet was found to be for interpersonal communication. ${ }^{15}$ A panel study of 1,910 Facebook users found (self-reported) that receiving personalized wall posts or comments from strong rather than weak ties improves psychological well-being. ${ }^{16}$ As such, displacing strong ties might result in negative symptoms and decreased well-being. Early research on the Internet's impact on well-being did not differentiate between activities online, i.e. communicating vs. surfing, and treated such activities as interchangeable and equally important in determining well-being outcomes. Similarly, newer SNS research appears to do the same. ${ }^{17}$ It is increasingly apparent that how online communication affects a person's mood depends on many factors such as how close the communication partners are and the nature of the communication exchange. ${ }^{18}$

Past studies have identified undesirable outcomes and risk factors for depression linked to consuming social information on Facebook. These risk factors include but are not limited to jealousy, ${ }^{19}$ social isolation (the experience of being separated from other people, which can exacerbate the underlying negative mental health states), ${ }^{20}$ increasing social tension ${ }^{21}$ and even

${ }^{14}$ C. HuAng. "Internet Use and Psychological Well-Being," Encyclopedia of Cyber Behavior, 302-14, doi:10.4018/978-1-4666-0315-8.ch026.

${ }^{15}$ KRAUT ET AL., Internet paradox.

${ }^{16}$ M. Burke and R. E. Kraut, "The Relationship Between Facebook Use and Well-Being Depends on Communication Type and Tie Strength," Journal of Computer-Mediated Communication 21, no. 4 (2016): 265-81, doi:10.1111/jcc4.12162.

${ }^{17}$ See R. Kraut and M. Burke, "Internet Use and Psychological Well-Being Effects of Activity and Audience," Communications of the ACM 58, no. 12 (2015): 94-100. doi:10.1145/2739043.

${ }^{18}$ HUANG, Internet Use and Psychological Well-Being; BuRKE and KRAUT, "The Relationship Between Facebook Use."

${ }^{19}$ A. Muise, E. Christofides, and S. Desmarais, "More Information than You Ever Wanted: Does Facebook Bring Out the Green-Eyed Monster of Jealousy?" CyberPsychology \& Behavior 12, no. 4 (2009): 441-44. doi:10.1089/cpb.2008.0263.

${ }^{20}$ M. Burke, C. Marlow, and T. Lento, "Social network activity and social well-being" (paper presented at the SIGCHI Conference on Human Factors in Computing Systems, Atlanta, GA, USA, April 10-15, 2010), https://doi.org/10.1145/1753326.1753613.

${ }^{21}$ D. BOYD and J. HEER, "Profiles as Conversation: Networked Identity Performance on Friendster," Proceedings of Thirty-Ninth Hawai'i International Conference on System Sciences (HICCSS-39) (Los Alamitos, CA: IEEE Press, 2006). 
fostering a state of fatigue resulting from "social overload." 22 As emphasized before, the relationship between Facebook and depression is one of complexity, with multiple different contributing factors. ${ }^{23}$ This complexity is highlighted by the available body of literature showing both a positive relationship, ${ }^{24}$ no significant relationship, ${ }^{25}$ and even a negative relationship ${ }^{26}$ between Facebook and depression. The lack of consensus could be partially due to the inherent difficulties in studying Facebook use, especially when using observational studies, which require great effort and time. ${ }^{27}$

Research study by Verduyn et al. ${ }^{28}$ using a method called experience sampling, where participants described their state or life experience at certain times during the day, revealed that specifically passive use but not active use of Facebook contributed to a decline in well-being, and this was a process completely mediated by envy - a harmful and painful feeling arising when user passively compares with other users and desires what others have. ${ }^{29}$

${ }^{22}$ GARTNER, "Gartner Survey Highlights Consumer Fatigue with Social Media," Your Story, accessed February 24, https://yourstory.com/2011/08/gartner-survey-highlights-consumer-fatiguewith-social-media.

${ }^{23}$ D. A. BAKER and G. P. Algorta, "The Relationship Between Online Social Networking and Depression: A Systematic Review of Quantitative Studies," Cyberpsychology, Behavior, and Social Networking 19, no. 11 (2016): 638-48, doi:10.1089/cyber.2016.0206.

${ }^{24}$ C. SAgioglou and T. Greitemeyer, "Facebooks Emotional Consequences: Why Facebook arouses a Decrease in Mood and Why People Still Use It," Computers in Human Behavior 35 (2014): 359-63, doi:10.1037/e514472015-239; C. J. BLOMFIELD and B. L. BARBER, "Social Networking Site Use: Linked to Adolescents' Social Self-Concept, Self-Esteem, and Depressed Mood," Australian Journal of Psychology 66, no. 1 (2014): 56-64, doi:10.1111/ajpy.12034.

${ }^{25}$ L. A. Jelenchick, J. C. Eickhoff, and M.A. Moreno, “'Facebook Depression?' Social Networking Site Use and Depression in Older Adolescents," Journal of Adolescent Health 52, no. 1 (2013): 128-30.

${ }^{26}$ N. Ellison, C. Steinfield, and C. LAmpe, "The Benefits of Facebook 'Friends': Social Capital and College Students' Use of Online Social Network Sites," Journal of ComputerMediated Communication 12, no. 4 (2007): 1143-68.; J. KIM and J. R. LEE, "The Facebook Paths to Happiness: Effects of the Number of Facebook Friends and Self-Presentation on Subjective Well-Being," Cyberpsychology, Behavior, and Social Networking 14, no. 6 (2011): 359-64, doi:10.1089/cyber.2010.0374; S. VAlenZuela, N. PARK, and K.F. KeE, "Is There Social Capital in a Social Network Site? Facebook Use and College Students Life Satisfaction," Trust, and Participation. Journal of Computer-Mediated Communication 14, no. 4 (2009): 875-901, doi:10.1111/j.1083-6101.2009.01474.x.

${ }^{27}$ H. B. SHAKYA and N. A. Christakis, "Association of Facebook Use with Compromised Well-Being: A Longitudinal Study,” American Journal of Epidemiology 185, no. 3 (2017): 20311, doi:10.1093/aje/kww189.

${ }^{28}$ VerduYn ET AL., "Passive Facebook usage."

${ }^{29}$ A. Pera, "Psychopathological Processes Involved in Social Comparison, Depression, and Envy on Facebook," Frontiers in Psychology 9, no. 22 (2018), doi:10.3389/fpsyg.2018.00022. 
A recent longitudinal study of 5,208 adults, with three waves of data analyzed over a time period of two years, looked at changes in self-reported measures of well-being (such as life satisfaction and mental health).$^{30}$ The authors had direct access to the participants' data, examining the metrics such as a frequency of "likes" pressed and links followed. The conclusion reached was that Facebook use had a markedly strong association with a decrease in mental health and well-being in the year following its use. Specifically, the number of status updates related to reports of lowered mental health, while pressing "like" buttons on others' content pages and posts consistently lowered well-being. It appears that the processes of "envy" and "comparison" are frequently found to be central mediating factors in the development of depressive symptoms and lowered well-being when using Facebook. The link between envy and depression is also found in research studies not involving Facebook. ${ }^{31}$ The study is more "solid" than its previous studies due to the nature of this particular type of study design, providing a stronger claim to any causal conclusion.

\section{ENVY AND SOCIAL COMPARISON ON FACEBOOK AND ITS CONSEQUENCES FOR MENTAL WELL-BEING}

In his book The Conquest of Happiness, ${ }^{32}$ the famous British philosopher Bertrand Russel wrote that envy was one of the most potent determinants of "unhappiness." Indeed, past research within social psychology reveals that the state of envy itself may generate frustration ${ }^{33}$ and mental distress ${ }^{34}-$ all of which are painful mental states. Envy, defined as "unpleasant and often painful blend of feelings caused by a comparison with a person or group of people who possess something we desire," is erosive to a person's wellbeing and life satisfaction. ${ }^{35}$ Envy leaves a person feeling discontented, not

\footnotetext{
${ }^{30}$ SHAKYA and CHRISTAKIS, "Association of Facebook Use."

${ }^{31}$ Y. Cohen-Charash, "Episodic Envy," Journal of Applied Social Psychology 39, no. 9 (2009): 2128-73; B. T. Gold, "Enviousness and its Relationship to Maladjustment and Psychopathology," Personality and Individual Differences 21, no. 3 (1996): 311-21, doi:10.1016/0191-8869(96)00081-5.

32 B. Russel, The Conquest of Happiness (London: Liveright,1930).

${ }^{33}$ A. Maurya, Running Lean: Iterate from Plan A to a Plan That Works (Sebastopol, CA: O’Reilly Media, Inc., 2012).

${ }^{34}$ M. J. PISKORSKI, "Social strategies that work," Harvard Business Review 89, no. 11(2011): 116-22.

${ }^{35}$ R. H. SмITH and S.H. KIM, "Comprehending Envy," Psychological Bulletin 133, no. 1 (2007): 46-64.
} 
appreciative of their qualities or possessions. Envy is triggered in Facebook users through repeated and frequent exposure to social information when passively browsing Facebook, ${ }^{36}$ and can significantly impair sense of life satisfaction and well-being. ${ }^{37}$ The scale of information found on Facebook in itself provides a natural ground for potential envy, a feeling which typically might arise when new information is learned about another person. ${ }^{38}$ Browsing Facebook for just ten minutes without active interaction can breed envy and lower affective well-being. ${ }^{39}$ Similarly, encountering positive information about other users while browsing the news feed is demonstrated to be capable of triggering feelings of envy, ${ }^{40}$ especially if this user is someone of familiar demographic background to oneself, possibly as the reference makes them more suitable for comparison. ${ }^{41}$ Additionally, envy behaviors and its outcomes might be augmented as individuals high on narcissistic traits or low in self-esteem are increasingly active users of Facebook and focus mainly on spreading self-promotional contents that may not always reflect the reality. ${ }^{42}$

Social information does not have to be especially self-aggrandizing to trigger envy. For example, a lonely individual perceiving someone receiving numerous birthday wishes has been demonstrated to elicit envious feelings. ${ }^{43}$ Furthermore, increased Facebook use predicts not only envy but greater jealousy, especially in romantic relationships, even when controlling for relationship factors and personality factors. ${ }^{44}$ The implications are also true for Facebook users in general; via surveillance behaviors and jealousy, this can result in problems of relationship dissatisfaction. ${ }^{45}$ Results from different

\footnotetext{
${ }^{36}$ KRASNOVA ET AL., "Envy on Facebook."

${ }^{37}$ SмITH and KIM, "Comprehending Envy."

${ }^{38}$ Ibid.

${ }^{39}$ VERduYn ET AL., "Passive Facebook usage."

${ }^{40}$ H. G. ChOU and N. Edge, “"They Are Happier and Having Better Lives than I Am': The Impact of Using Facebook on Perceptions of Others Lives," Cyberpsychology, Behavior, and Social Networking 15, no. 2 (2012): 117-21, doi:10.1089/cyber.2011.0324.

${ }^{41}$ SMITH and KIM, "Comprehending Envy."

${ }^{42}$ S. MehdizadeH, "Self-Presentation 2.0: Narcissism and Self-Esteem on Facebook," Cyberpsychology, Behavior, and Social Networking 13, no. 4 (2010), doi:10.1089/cpb.2009.0257.

${ }^{43}$ Burke, Marlow, and Lento, "Social Network Activity and Social Well-Being."

${ }^{44}$ A. Muise, E. Christofides, and S. Desmarais, "More Information than You Ever Wanted: Does Facebook Bring Out the Green-Eyed Monster of Jealousy?" CyberPsychology \& Behavior 12, no. 4 (2009): 441-44, doi:10.1089/cpb.2008.0263.

${ }^{45}$ R. A. Elphinston and P. Noller, "Time to Face It! Facebook Intrusion and the Implications for Romantic Jealousy and Relationship Satisfaction," Cyberpsychology, Behavior, and Social Networking 14, no. 11 (2011): 631-35, doi:10.1089/cyber.2010.0318.
} 
studies reach conclusions emphasizing the importance of differentiating types of Facebook use. Using it passively, it can lead to depressive symptoms, completely mediated by envy. ${ }^{46}$ Envy seriously contributes to "Facebook depression," and it is argued that the painful feeling of envy is a principal factor that contributes to depression by lowering life satisfaction (our own judgment of our life quality as a whole). ${ }^{47}$

Another factor predicting lowered well-being while using Facebook is social comparison. Social comparison occurs in real-life situations, but on social media websites, social information is more readily available for comparison than in offline settings. ${ }^{48}$ Evidence from cross-sectional studies suggests that the more people use Facebook, the more they compare themselves to others on Facebook. ${ }^{49}$ Some people can trigger depression through frequent and persistent comparison behaviors. The self-regulatory perseveration theory of depression ${ }^{50}$ suggests that people can become depressed through persistent self-focus on an unattainable goal, thus ruining their self-esteem. For example, frequent viewing of other people's yacht photos on Facebook may affect negatively self-esteem. The theory is supported by studies showing a tendency towards "high self-awareness" in people that are depressed, and reducing this tendency tends to reduce depressive symptoms. ${ }^{51} \mathrm{~A}$ person who is high on self-awareness is more aware of themselves, their possessions and life situation and more likely to make comparisons, which potentially

${ }^{46}$ VerduYn ET AL., "Passive Facebook usage."

${ }^{47}$ KrASNOVA ET AL., "Envy on Facebook."

${ }^{48}$ N. HAFERKAmP and N. C. KRÄMER, "Social Comparison 2.0: Examining the Effects of Online Profiles on Social-Networking Sites," Cyberpsychology, Behavior, and Social Networking 14, no. 5 (2011): 309-14, doi:10.1089/cyber.2010.0120; E. A. Vogel, J. P. Rose, L. R. Roberts, and K. ECKLES (2014). "Social media, social comparison, and self-esteem," Cyberpsychology, Behavior, and Social Networking 1, no. 5 (2011): 309-14, doi:10.1037/e512142015-699.

${ }^{49}$ For example, Vogel ET AL., "Social Media, Social Comparison"; E. A. Vogel ET AL., "Who Compares and Despairs? The Effect of Social Comparison Orientation on Social Media Use and Its Outcomes," Personality and Individual Differences 86 (2015): 249-56, doi:10.1016/j.paid. 2015.06.026; E. LeE, Y. J. Kim, and J. Ahn, "How Do People Use Facebook Features to Manage Social Capital?" Computers in Human Behavior 36 (2014): 440-45; M-L. STEERS, R. E. WiCKHAM, and L. ACitelli, "Seeing Everyone Else's Highlight Reels: How Facebook Usage is Linked to Depressive Symptoms," Journal of Social and Clinical Psychology 33, no. 8 (2014): 701-31.

${ }^{50}$ T. PyszcZynski and J. GreenBerg, "Toward an Integration of Cognitive and Motivational Perspectives on Social Inference: A Biased Hypothesis-Testing Model," in Advances in Experimental Social Psychology, ed. Leonard Berkowitz, 20: 297-340 (San Diego, CA: Academic Press, 1987); J. Greenberg ET AL., "Why Do People Need Self-Esteem? Converging Evidence That Self-Esteem Serves and Anxiety-Buffering Function," Journal of Personality and Social Psychology 63, no. 6 (1992): 913-22.

51 Ibid. 
increases depressive states. It might seem plausible then, that if a person derives his or her self-esteem mostly from their Facebook identity, continuous impression management without ever reaching the ultimate "goal" may contribute to depression. ${ }^{52}$

Painful feelings of envy and social comparisons are frequently reported as stressors $^{53}$ as well as a source of frustration - an emotional response that arises due to perceiving oneself as "blocked" from fulfilling the individual's will or "goal." Negative social comparison is a risk factor for rumination and worry which in turn, can contribute to depressive symptoms. ${ }^{54}$ Humans also tend to share positive news about themselves and seek to present a selfenhancing image. ${ }^{55}$ Therefore, the content which is disseminated via Facebook tends to be positively skewed and less truly intimate, serving as a fertile base for potential negative social comparison. ${ }^{56}$ This may be because users want to be viewed positively by their friends, ${ }^{57}$ in combination with the awareness of communicating to a generally large social circle, and as such, users may strategically communicate "proper" content for reasons of self-presentation. ${ }^{58}$ Furthermore, other users generally perceive positive posts more favorably than negative posts. ${ }^{59}$ This can result in misperceptions, frequently overestimating other people's happiness while underestimating others' difficulties. ${ }^{60}$ Related studies on Facebook comparison have found experi-

\footnotetext{
${ }^{52}$ Haferkamp and KRÄMER, "Social Comparison 2.0"; Vogel et AL., "Social Media, Social Comparison."

53 J. Fox and J. J. Moreland, "The Dark Side of Social Networking Sites: An Exploration of the Relational and Psychological Stressors Associated with Facebook Use and Affordances," Computers in Human Behavior 45 (2015): 168-76, doi:10.1016/j.chb.2014.11.083.

${ }^{54}$ B. A. Feinstein ET AL., "Negative Social Comparison on Facebook and Depressive Symptoms: Rumination as a mechanism," Psychology of Popular Media Culture 2, no. 3 (2013): 16170, doi:10.1037/a0033111.

${ }^{55}$ E. Goffman, The Presentation of Self in Everyday Life (New York: Doubleday Anchor Books, 1959).

${ }^{56}$ N. N. BaZARova ET AL., "Social Sharing of Emotions on Facebook: Channel Differences, Satisfaction, and Replies," Computer Supported Cooperative Work (March 14-18, 2015): 154-64.

${ }^{57}$ A. NAdkarni and S. G. Hofmann, "Why Do People Use Facebook?" Personality and Individual Differences 52, no. 3 (2012): 243-49.

${ }^{58}$ N. N. BAZAROVA ET AL., "Managing Impressions and Relationships on Facebook: Self-presentational and Relational Concerns Revealed through the Analysis of Language Style," Journal of Language and Social Psychology 32 (2013): 121-41, doi:10.1177/0261927X12456384.

${ }^{59}$ N. N. BAZAROvA, "Public Intimacy: Disclosure Interpretation and Social Judgments on Facebook," Journal of Communication 62, no. 5 (2012): 815-32, doi:10.1111/j.1460-2466.2012. 01664.

${ }^{60}$ A. JORDAN ET AL., "Misery Has More Company Than People Think: Underestimating the Prevalence of Others' Negative Emotions," Personality and Social Psychology Bulletin 37, no. 1 (2011): 120.
} 
ences of diminished self-esteem ("ego deflation"), envy with following depressive feelings. ${ }^{61}$ Driver \& Gottman ${ }^{62}$ did studies on newlyweds and relationships and found that how people respond to what he refers to as "emotional bids" (calls for support) over time, determines relationship quality. In the context of the evolutionary sociometer theory, human self-esteem works as a gauge ("sociometer") - an indicator of how the person is accepted and valued. ${ }^{63}$ Therefore, getting no "likes" or comments can indicate to the user that he or she is not valued or accepted, thus predicting lowered well-being and self-esteem, which is again predictive of mild depression. ${ }^{64}$ Negative comments, which are perceived as "turning against" one's emotional bid may lead to social withdrawal correlated positively with depression. ${ }^{65}$ The available evidence is consistent with the understanding that unfavorable social comparisons and envy are relevant factors that may lead to depression and lowered well-being. ${ }^{66}$

\section{OTHER MECHANISMS FACILITATING DEPRESSIVE STATES ON FACEBOOK}

There are also many other mechanisms that likely facilitate depressive states of Facebook users. For example, one study found that deterioration of mood after using Facebook was explained by a feeling of having wasted

\footnotetext{
${ }^{61}$ SteErs et AL., "Seeing Everyone Else's Highlight Reels"; ChOu and EdGE, “"They Are Happier and Having Better Lives than I Am': The Impact."

${ }^{62}$ J. L. Driver and J. M. GotTman. "Daily Marital Interactions and Positive Affect During Marital Conflict Among Newlywed Couples," Family Process 43, no. 3 (2004): 301-14, doi:10.1111/j. 1545-5300.2004.00024.x.

${ }^{63}$ M. LEARY ET AL., "Self-Esteem as an Interpersonal Monitor: The Sociometer Hypothesis," Journal of Personality and Social Psychology 68, no. 3 (1995): 518-30.

${ }^{64}$ C. R. Blease, "Too Many 'Friends,' Too Few 'Likes'? Evolutionary Psychology and 'Facebook Depression'," Review of General Psychology 19, no. 1 (2015): 1-13.

${ }^{65}$ DRIVER and GOTTMAN, "Daily Marital Interactions."

${ }^{66}$ B. A. Feinstein, "Negative Social Comparison on Facebook and Depressive Symptoms: Rumination as a Mechanism," Psychology of Popular Media Culture 2, no. 3 (2013): 161-70, doi:10.1037/a0033111; J. NeSI and M. J. PrInSTEIN (2015), "Using Social Media for Social Comparison and Feedback-Seeking: Gender and Popularity Moderate Associations with Depressive Symptoms," Journal of Abnormal Child Psychology 43, no. 8 (2013): 1427-38, doi: 10.1007/s10802-015-0020-0; S. Y. LEE, "How do people compare themselves with others on social network sites? The Case of Facebook," Computers in Human Behavior 32 (2014): 253-60, doi:10.1016/j.chb.2013.12.009; H. ApPel, A. L. Gerlach, and J. Crusius, "The Interplay Between Facebook Use, Social Comparison, Envy, and Depression," Current Opinion in Psychology 9 (2016): 44-49, doi:10.1016/j.copsyc.2015.10.006.
} 
one's time, or not having done anything meaningful. ${ }^{67}$ Further, spending large amounts of time on Facebook may detract from the possibility of having other meaningful real-life experiences. ${ }^{68}$

Despite evidence suggesting negative effects of Facebook use, people persist in using it. One of the reasons for this is that people often expect to feel better after using Facebook, when often this is not true - a process called committing to a forecasting error, that describes the difference between the actual or real and the predicted or forecasted value of an activity or any other phenomenon. ${ }^{69}$ Another study applied the concept of "communication overload" (stress resulting from an overload of communication messages and demands) in the implication of mental health and Facebook use, showing another nuance of the Facebook and depression linkage. ${ }^{70}$ Specifically, it was found that communication overload leads to psychological distress through a loss of self-esteem. ${ }^{71}$ Another negative aspect of Facebook use is the phenomenon of "cyberbullying," demonstrated to potentially occur while using Facebook and to have negative interpersonal and mental health effects. Studies show that Facebook can be used as a medium to victimize fellow Facebook users, leading to depression and decreased well-being of the victims. ${ }^{72}$ Another possible contributing factor is boredom. Eastwood et al. ${ }^{73}$ conducted a meta-analysis of boredom and found that boredom arises as a result of a lack of attention and failure to engage that subsequently may initiate media multitasking. This becomes especially relevant in the context of social media, something that occurs because of Facebook use and that bears with it a task-switching cost. Facebook use initiates multitasking and is itself associated with both task-switching and multitasking. ${ }^{74}$ Facebook is designed

${ }^{67}$ SAgioglou and Greitemeyer, "Facebooks Emotional Consequences."

${ }^{68}$ H. B. ShAKYA and N. A. Christakis, "Association of Facebook Use with Compromised Well-Being: A Longitudinal Study," American Journal of Epidemiology 185, no. 3 (2017), doi:10.1093/aje/kww189.

${ }^{69}$ P. WALLSTRÖM, Evaluation of Forecasting Techniques and Forecast Errors with Focus on Intermittent Demand (Luleå, Sweden: Luleå University of Technology, 2009), https://www.divaportal.org/smash/get/diva2:990519/FULLTEXT01.pdf.

70 J. CHO ET AL., "The Rate and Delay in Overload: An Investigation of Communication Overload and Channel Synchronicity on Identification and Job Satisfaction," Journal of Applied Communication Research 39 (2011): 38-54, doi:10.1080/00909882.2010.536847.

${ }^{71}$ CHO ET AL., "The rate and delay in overload."

${ }^{72}$ G. C. E. KWAN and M. M. SKORIC, "Facebook Bullying: An Extension of Battles in School," Computers in Human Behaviour 29, no. 1 (2013): 16-25.

73 J. D. EAstwood ET AL., "The Unengaged Mind: Defining Boredom in Terms of Attention," Perspectives on Psychological Science 7, no. 5 (2012): 482-95.

${ }^{74}$ T. JudD, "Task Selection, Task Switching and Multitasking During Computer-Based Independent Study," Australasian Journal of Educational Technology 31, no. 2 (2011): 120. 
to offer many things pulling at users attention, thus, they may become less able to meaningfully engage in whatever they are doing. This state of boredom and lack of ability to be attentive to whatever one is doing creates discontent. ${ }^{75}$

Some studies specifically demonstrate that alerts and notifications (typical of Facebook) cause a shift in attention through task interruption and create task-irrelevant thoughts that might increase procrastination. ${ }^{76}$ The efforts to maintain attention are prompted into mind-wandering, which can be detrimental to task performance. ${ }^{77} \mathrm{~A}$ study of students from middle school to university level found that a significant number of students frequently report that "because of Facebook" they lose track of time and delay normally planned tasks. ${ }^{78}$ This media-induced task-switching during academic work is driven by the hedonic high pleasure and arousal induced by being on Facebook in combination with deficient control over the switching behavior. ${ }^{79}$ Lack of control and "media-induced task switching" is demonstrated to be detrimental to students' well-being. ${ }^{80}$ A study of 354 students Facebook users supported these findings examining the notion that "Facebocrastination" impairs academic and overall well-being. ${ }^{81}$ The authors consistently found that $40 \%$ of the variation of using Facebook for procrastinating academic tasks could be explained by low innate self-control, degree of habitual Face-

${ }^{75}$ Eastwood et AL., "The Unengaged Mind."

${ }^{76}$ M. Pielot, K. Church, and R. D. Oliveira, "An In-Situ Study of Mobile Phone Notifications," in MobileHCI '14 Proceedings of the 16th International Conference on HumanComputer Interaction with Mobile Devices \& Services (New York, NY: ACM, 2014); C. STOTHART, A. Mitchum, and C. Yehnert, "The Attentional Cost of Receiving a Cell Phone Notification," Journal of Experimental Psychology Human Perception \& Performance 41, no. 4 (2015): 89397, doi:10.1037/xhp0000100.

${ }^{77}$ Ibid.

${ }^{78}$ L. D. Rosen, L. M. CARrier, and N. A. CheEver, "Facebook and Texting Made Me Do It: Media-Induced Task-Switching While Studying," Computers in Human Behaviour 29, no. 3 (2013): 948-58.

79 P. DAVID ET AL., "Mobile phone distraction while studying," New Media \& Society 17, no. 10 (2015): 1661-79, doi:10.1177/1461444814531692; W.A. SChUUR ET AL. (2015), "The Consequences of Media Multitasking for Youth: A Review," Computers in Human Behavior 53 (2015): 204-15, doi:10.1016/j.chb.2015.06.035; S. Xu, Z. WANG, and D. PraBu, "Media Multitasking and Well-Being of University Students," Computers in Human Behavior 55, 242-50, doi:10.1016 /j.chb.2015.08.040.

${ }^{80}$ Rosen ET AL., "Facebook and Texting Made Me Do It."; Xu ET AL., "Media Multitasking and Well-Being of University Students."

${ }^{81}$ A. Meier, L. Reinecke, and C. E. Meltzer, "Facebocrastination"? Predictors of Using Facebook for Procrastination and Its Effects on Students' Well-Being," Computers in Human Behavior 64 (2016): 65-76, doi:10.1016/j.chb.2016.06.011. 
book checking, and high enjoyment of Facebook use. This study also found that procrastinating academic tasks undermined users' overall well-being and elevated stress levels. The Facebook procrastination effects on wellbeing extended beyond the academic domain including (for example) momentary mood and personal relationships. Moreover, individuals that often and habitually checked Facebook to stay "connected," seem especially prone to dysfunctional Facebook use. Even though the study was cross-sectional, it supports the previous findings that uncontrolled and dysfunctional use of Facebook is detrimental to one's short-term and longer-term well-being.

It was especially "high enjoyment of Facebook use" that predicted procrastination. ${ }^{82}$ People tend to approach Facebook to fulfil needs of relatedness and competence, which secondarily elevates subjective well-being, and this is perceived as an overall highly enjoyable process for the user. ${ }^{83}$ This pleasurable media experience is a behavior that people frequently desire to take part in. ${ }^{84}$ Using operant conditioning (a form of learning), people learn to approach media stimuli to improve mood states and well-being. ${ }^{85} \mathrm{Howev-}$ er, considering the effects of procrastination on well-being, the temporary positive affective state one derives from Facebook procrastination appears to diminish relatively quickly, typically disappearing the moment the user cognitively realizes he or she could have been more productive, and when he or she understands that their behavior was driven by a lack of self-control. ${ }^{86}$ Procrastination on Facebook affects short-term well-being in at least two ways, through the principal mechanism of self-regulatory failure: by triggering negative (and self-conscious) emotions, and by reducing the immediate gratification benefits one receives when using this technology. There is also evidence to support that, concerning procrastinatory behavior, longer-term well-being is affected ${ }^{87}$ In a longitudinal study, Hinsch and Sheldon found that reducing Facebook use translated into increased satisfaction with life

82 Ibid.

${ }^{83}$ L. Reinecke, T. Hartmann, and A. Eden, "The Guilty Couch Potato: The Role of Ego Depletion in Reducing Recovery through Media Use," Journal of Communication 64, no. 4 (2014): 569-89; K. M. Sheldon, N. ABAD, and C. Hinsch, "A Two-Process View of Facebook Use and Relatedness Need-Satisfaction: Disconnection Drives Use, and Connection Rewards It," Journal of Personality and Social Psychology 100, no. 4 (2011): 766-75.

${ }^{84}$ S. G. HofmAnN ET AL., "The Efficacy of Cognitive Behavioral Therapy: A Review of Meta-Analyses," Cognitive Therapy and Research 36, no. 5 (2012): 427-40.

85 D. ZillmanN, "Mood Management Through Communication Choices," American Behavioral Scientist 31, no. 3 (1988): 327-41.

86 SAgioglou and Greitemeyer, "Facebooks Emotional Consequences."

${ }^{87}$ C. Hinsch and K. M. SHELdON, "The Impact of Frequent Social Internet Consumption: Increased Procrastination and Lower Life Satisfaction," Journal of Consumer Behaviour 12, no. 6 (2013): 496-505. 
over time. The mechanism was mediated primarily by a decrease in procrastination. ${ }^{88}$ Well-being is also affected by later bedtimes and worse sleep quality related to procrastination and use of technological devices. ${ }^{89}$ People often (erroneously) expect to feel better after using Facebook, but in fact, the feeling of having wasted time cognitively impacts mood in a negative way and contributes to declining well-being. ${ }^{90}$ Moreover, as users' become aware of their performance decreasing due to Facebook procrastination, they start to ruminate and worry ${ }^{91}$ (Stöber and Joormann, 2001; Flett et al., 2012), with resulting states of increased anxiety and potentially worsened well-being. ${ }^{92}$ Users' also feel guilty about procrastinating Facebook use ("guilty pleasure"), and the emotion of guilt itself can undermine the pleasure of immediate gratification. ${ }^{93}$ Reinecke et al. ${ }^{94}$ found that guilt eventually caused media use to be less enjoyable and contributed to users' lower well-being. In other words, all the mentioned processes leading to users' negative self-evaluations showed to impair the Facebook procrastinators' psychological well-being.

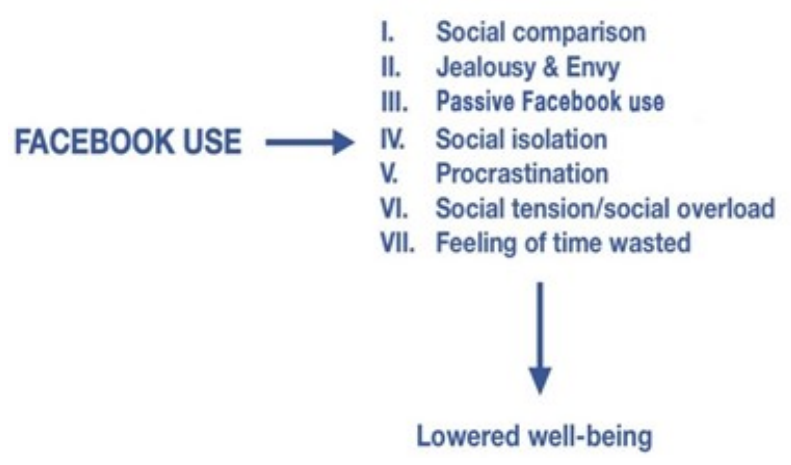

The Author's flowchart depicting the many potential processes leading to a state of lowered well-being.

\footnotetext{
${ }^{88}$ Ibid.

${ }^{89}$ For example, N. CAIN and M. GRADISAR, "Electronic Media Use and Sleep in School-Aged Children and Adolescents: A Review," Sleep Medicine 11, no. 8 (2010): 735-42.

${ }^{90}$ Sagioglou and Greitemeyer, "Facebooks Emotional Consequences."

${ }^{91}$ J. StÖBer and J. JoOrmann, "Worry, Procrastination, and Perfectionism: Differentiating Amount of Worry, Pathological Worry, Anxiety, and Depression," Cognitive Therapy and Research 25, no. 1 (2001): 49-60, doi:10.1023/A:1026474715384; G. L. FLETT ET AL., "Procrastination Automatic Thoughts as a Personality Construct: An Analysis of the Procrastinatory Cognitions Inventory," Journal of Rational-Emotive \& Cognitive Behavior Therapy 30, no. 4 (2012): 233-36.

${ }^{92}$ C. H. Lay and H. C. Schouwenburg, "Trait Procrastination, Time Management, and Academic Behavior," H C Journal of Social Behavior and Personality 8, no. 4 (1993): 647.

${ }^{93}$ MeIER ET AL., “'Facebocrastination'?”; J. G. MYrICK, "Emotion Regulation, Procrastination, and Watching Cat Videos Online: Who Watches Internet Cats, Why, and to What Effect?" Computers in Human Behavior 52 (2015): 168-76, doi:10.1016/j.chb.2015.06.001.

${ }^{94}$ Reinecke eT AL., "The Guilty Couch Potato."
} 


\section{CONCLUSION}

With the accelerated technological progress and rapid development of social media, researchers are increasingly interested in the changes introduced by computer use and the Internet, in particular, and the many intricate ways these technologies are transforming economic and social life. ${ }^{95}$ Social media have changed the ways people communicate and satisfy their social, belonging and connectedness needs that are tightly correlated with obtaining wellbeing. ${ }^{96}$ Subsequently these changes have shown to influence people's health in broader sense and on many levels of investigation, ${ }^{97}$ leading to eventually more serious health concerns that present an economically valid problem of creating and maintaining systems and services targeting negative physical and mental health consequences of Facebook and SNS use such as: depression, ${ }^{98}$ cyberbullying, ${ }^{99}$ and lowered well-being. ${ }^{100}$ Considering these circumstances the outcomes of using Facebook and other social media progressively capture interest of not only scientists but also policy makers and a broad spectrum of economic entities.

The current available data is still not fully sufficient for conducting experiments investigating not only the innate processes of how Facebook use

${ }^{95}$ R. H. ANDERSOn ET AL., eds., Universal Access to E-mail: Feasibility and Societal Implications (Santa Monica, CA: Rand Corporation, 1995); J. L. KING and K. L. KraEmER, "ComputerBased Models for Policy-Making: Uses and Impacts in the U.S. Federal Government," in Information Systems in the Political World, ed. K. V. Andersen, 129-46 (Amsterdam: IOS Press, 1995).

${ }^{96}$ N. Ellison, C. Steinfield, and C. LAMPE, "The Benefits of Facebook 'Friends': Social Capital and College Students' Use of Online Social Network Sites," Journal of Computer-Mediated Communication 12, no. 4 (2007): 1143-68; M. Burke, C. MARlow, and T. Lento, "Social Network Activity and Social Well-Being," paper presented at the SIGCHI Conference on Human Factors in Computing Systems, Atlanta, GA, USA, April 10-15, 2010, https://oi.org/10.1145/ 1753326.1753613; K. Johnston ET AL., "Social Capital: The Benefit of Facebook 'Friends'," Behaviour \& Information Technology 32, no. 1 (2013): 24-36; E. LEE, Y. J. KIM, and J. AHN, "How Do People Use Facebook Features To Manage Social Capital?" Computers in Human Behavior 36 (2014): 440-45.

${ }^{97}$ BurKe and Kraut, "The Relationship Between Facebook Use"; Ellison, STEINFIEld, and LAMPE, "The Benefits of Facebook "Friends"”; KRAut eT AL., "Internet Paradox"; Sutcliffe ET AL., "Systematic Review of Communication Technologies to Promote Access and Engagement of Young People With Diabetes into Healthcare," BMC Endocrine Disorders 11, no. 1 (2011), doi:10.1186/1472-6823-11-1.

${ }^{98}$ L. GuernSEY, “A Cautionary Tale of Pediatricians, Parents, and Facebook," February 19, 2014, http://www.slate.com/blogs/future_tense/2014/02/19/facebook_depression_scare_offers_a _cautionary_tale_of_pediatricians_parents.html?via=gdpr-consent.

${ }^{99}$ KWAN and SKORIC, "Facebook bullying."

${ }^{100}$ LAY and Schouwenburg, "Trait Procrastination, Time Management, and Academic Behavior." 
influences one's well-being but also the potential macro-economic consequences of negative health and well-being outcomes caused by Facebook use. Nevertheless, since Facebook's negative impact on users' well-being is of big interest to the scientific community, it probably will not be long before such data becomes more complete and accessible.

As clearly presented in this review, there are many nuanced and potentially highly negative well-being issues stemming from Facebook use. So far, research has classified troublesome outcomes and risk factors of depression linked to consuming and interacting with social information on Facebook. They include but are not limited to: negative social comparison ${ }^{101}$ ), jealousy, ${ }^{102}$ envy, ${ }^{103}$ surveillance behaviors, ${ }^{104}$ social isolation (the experience of being separated from other people, which can exacerbate underlying negative mental health states), ${ }^{105}$ procrastination, ${ }^{106}$ increasing social tension, ${ }^{107}$ and even fostering a state of fatigue resulting from "social overload." 108 The scientific community agrees that Facebook has the potential to elicit depressive symptoms and lower well-being of its users, but this depends on many factors such as the individual's constitution and personality, type of Facebook use (passive or active), and the frequency of use ("addiction"). Nevertheless, the causal relationship between Facebook and depression is not sufficiently established. Studies find that a passive use specifically predicts envy and social comparison effects that can be detrimental to mental health. As we have seen, several factors may be involved. Further experiments are

${ }^{101}$ For example, Vogel ET AL., "Social Media, Social Comparison, and Self-Esteem"; S. Y. LEE, "How Do People Compare Themselves With Others On Social Network Sites? The Case of Facebook," Computers in Human Behavior 32 (2014), 253-60, doi:10.1016/j.chb.2013.12.009; M-L. Steers, R. E. Wickham, and L. K. Acitelli, "Seeing Everyone Else's Highlight Reels: How Facebook Usage is Linked to Depressive Symptoms," Journal of Social and Clinical Psychology 33, no. 8 (2014): 701-31; VoGEL ET AL., "Who compares and despairs?"

102 Muise ET AL., "More Information than You Ever Wanted."

103 VERDUYN ET AL., "Passive Facebook Usage."

${ }^{104}$ R. A. ElPhinston and P. NOLLER, "Time to Face It! Facebook Intrusion and the Implications for Romantic Jealousy and Relationship Satisfaction," Cyberpsychology, Behavior, and Social Networking 14, no. 11 (2011): 631-35, doi:10.1089/cyber.2010.0318.

105 BURKe ET AL., "Social Network Activity and Social Well-Being."

106 Rosen et AL., "Facebook and Texting Made Me Do It."; MeIer, ReineCCKe, and MELTZER, "“Facebocrastination"”?

${ }^{107}$ D. Boyd, "Friendster Lost Steam. Is MySpace Just a Fad?" Apophenia Blog (March 21, 2006), http://www.danah.org/papers/FriendsterMySpaceEssay.html.

${ }^{108}$ CHO ET AL., "The Rate and Delay In Overload: An Investigation of Communication Overload and Channel Synchronicity on Identification and Job Satisfaction," Journal of Applied Communication Research 39 (2011): 38-54, doi:10.1080/00909882.2010.536847. 
needed, using experience sampling or longitudinal studies to investigate causal links.

\section{BIBLIOGRAPHY}

Anderson, Robert H., Tora K. Bikson, Sally Ann LAw, and Bridger M. Mitchell, eds. Universal Access to E-mail: Feasibility and Societal Implications. Santa Monica: Rand Corporation, 1995.

Antheunis, Marjolijn L., Mariek Vanden Abeele, and Saskia Kanters. "The Impact of Facebook Use on Micro-Level Social Capital: A Synthesis.” Societies 5 (2015): 399-419.

Appel, Helmut, Alexander L. Gerlach, and Jan Crusius. "The Interplay Between Facebook Use, Social Comparison, Envy, and Depression." Current Opinion in Psychology 9 (2016): 44-49. doi:10.1016/j.copsyc.2015.10.006.

BAKer, David A., and Guillermo Perez Algorta. "The Relationship Between Online Social Networking and Depression: A Systematic Review of Quantitative Studies." Cyberpsychology, Behavior, and Social Networking 19, no. 11 (2016): 638-48. doi:10.1089/cyber.2016.0206.

BazArova, Natalya N., Yoon Hyung Choi, Victoria Schwanda Sosik, Dan Cosley, and Janis Leann WhitLock. "Social Sharing of Emotions on Facebook: Channel Differences, Satisfaction, and Replies." Computer Supported Cooperative Work. The Journal of Collaborative Computing and Work Practices (March 14-18, 2015): 154-64.

BAzArova, Natalya N. "Public Intimacy: Disclosure Interpretation and Social Judgments on Facebook." Journal of Communication 62, no. 5 (2012): 815-32. doi:10.1111/j.1460-2466. 2012.01664.x.

Bazarova, Natalya N., Jessie G. TAFT, Yoon Hyung ChoI, and Dan Cosley. "Managing Impressions and Relationships on Facebook: Self-Presentational and Relational Concerns Revealed through the Analysis of Language Style." Journal of Language and Social Psychology 32 (2013): 121-41.doi:10.1177/0261927X12456384

Bell, Daniel (1973). The Coming of Post-industrial Society: A Venture in Social Forecasting. New York, NY: Basic Books, 1973.

BŁachnio, Agata, Aneta PrzePiorka, and Juan F. Díaz-Morales. "Facebook Use and Chronotype: Results of a Cross-sectional Study." Chronobiology International 32 (2015): 1315-19. doi:10.3109/07420528.2015.1083998.

BŁachnio, Agata, Aneta Przepiórka, and Igor Pantic. "Internet Use, Facebook Intrusion, and Depression: Results of a Cross-Sectional Study.” European Psychiatry 30 (2015): 681-84. doi:10.1016/j.eurpsy.2015.04.002.

Blease, C. R. "Too Many 'Friends,' Too Few 'Likes'? Evolutionary Psychology and 'Facebook Depression'.” Review of General Psychology 19, no. 1 (2015): 1-13.

Blomfield Neira, Corey J., and Bonnie L. BARber. "Social Networking Site Use: Linked to Adolescents' Social Self-Concept, Self-Esteem, and Depressed Mood." Australian Journal of Psychology 66, no. 1 (2014): 56-64. doi:10.1111/ajpy.12034.

Boyd, Danah. "Friendster Lost Steam. Is MySpace Just a Fad?" Posted on Apophenia Blog (March 21, 2006). http://www.danah.org/papers/FriendsterMySpaceEssay.html. 
Boyd, Danah, and Jeffrey HeER. "Profiles as Conversation: Networked Identity Performance on Friendster." In Proceedings of Thirty-Ninth Hawai'i International Conference on System Sciences (HICCSS-39). Los Alamitos, CA: IEEE Press, 2006.

BoyD, Danah. "Friends, Friendsters, and MySpace Top 8: Writing Community into Being on Social Network Sites." First Monday 11, no. 12 (2006a, December 4). http://www.first monday.org/issues/issue11_12/boyd.

Burke, Moira, and Robert E. Kraut. "The Relationship between Facebook Use and Well-Being Depends on Communication Type and Tie Strength." Journal of Computer-Mediated Communication 21, no. 4 (2016): 265-81. doi:10.1111/jcc4.12162.

Burke, Moira, Cameron Marlow, and Thomas Lento. "Social Network Activity and Social Well-Being." In CHI '10: Proceedings of the SIGCHI Conference on Human Factors in Computing Systems (Atlanta, GA, April 10-15, 2010), 1909-12. https://doi.org/10.1145/ 1753326.1753613 .

Burke, Moira, and Robert Kraut. "Using Facebook after Losing a Job: Differential Benefits of Strong and Weak Ties," In Proceedings of the 2013 Conference on Computer-Supported Cooperative Work (February 2013), 1419-30. https://doi.org/10.1145/2441776.2441936.

Burke, Moira, Cameron Marlow, and Thomas Lento. "Social Network Activity and Social Well-Being." Paper presented at the SIGCHI Conference on Human Factors in Computing Systems, Atlanta, GA, USA, April 10-15, 2010. https://doi.org/10.1145/1753326.1753613.

Cain, Neralie, and Michael Gradisar (2010). "Electronic Media Use and Sleep in School-Aged Children and Adolescents: A Review.” Sleep Medicine 11, no. 8 (2010): 735-42.

Caruana, Edward J., Marius Roman, Jules Hernández-SÁnchez, and Piergiorgio Solli. "Longitudinal Studies.” Journal of Thoracic Disease 7, no. 11 (2015): 537-40.

Chen, Wenhong, and Kye Hyoung-LeE. "Sharing, Liking, Commenting, and Distressed? The Pathway between Facebook Interaction and Psychological Distress." Cyberpsychology, behavior, and social networking 16, no. 10 (2013): 728-34.

Chou, Hui-Tzu G., and Nicolas Edge. “'They Are Happier and Having Better Lives Than I Am': The Impact of Using Facebook on Perceptions of Others' Lives." Cyberpsychology, Behavior, and Social Networking 15, no. 2 (2012): 117-21. doi:10.1089/cyber.2011.0324.

Cho, Jaehee, Dina I. Ramgolam, Kimberly M. Schaefer, and Anu N. SAndlin. "The Rate and Delay in Overload: An Investigation of Communication Overload and Channel Synchronicity on Identification and Job Satisfaction." Journal of Applied Communication Research 39 (2011): 38-54. doi:10.1080/00909882.2010.536847.

Cohen-Charash, Yochi. "Episodic Envy." Journal of Applied Social Psychology 39, no. 9 (2009): 2128-73.

David, Prabu, Jung-Hyun Kim, Jared H. Brickman, Weina RAN, and Christine M. Curtis. "Mobile Phone Distraction While Studying." New Media \& Society 17, no. 10 (2015): 166179. doi:10.1177/1461444814531692.

Driver, Janice L., and John M. Gottman. "Daily Marital Interactions and Positive Affect during Marital Conflict among Newlywed Couples." Family Process 43, no. 3 (2004): 301-14. doi:10.1111/j.1545-5300.2004.00024.x.

EAstwood, John D., Alexandra Frischen, Mark J. Fenske, and Daniel SmileK. "The Unengaged Mind: Defining Boredom in Terms of Attention." Perspectives on Psychological Science 7, no. 5 (2012): 482-95. 
Ellison, Nicole, Steinfield, Charles, and Cliff LAMPE. "The Benefits of Facebook 'Friends': Social Capital and College Students' Use of Online Social Network Sites." Journal of Computer-Mediated Communication 12, no. 4 (2007): 1143-68.

Elphinston, Rachel A., and Patricia Noller. "Time to Face It! Facebook Intrusion and the Implications for Romantic Jealousy and Relationship Satisfaction.” Cyberpsychology, Behavior, and Social Networking 14, no. 1 (2011): 631-35. doi:10.1089/cyber.2010.0318.

EpPler, Martin, and Jeanne Mengis. "The Concept of IO: A Review of Literature from Organization Science, Marketing, Accounting, MIS and Related Disciplines." The Information Society: An International Journal 20, no. 5 (2004): 1-20.

Etchegoyen, Horacio R., and Clara R. Nemas. "Salieris Dilemma: A Counterpoint Between Envy and Appreciation.” The International Journal of Psychoanalysis 84, no. 1 (2003): 4558. doi:10.1516/00207570360509673.

Feinstein, Brian A., Rachel Hershenberg, Vickie Bhatia, Jessica A. Latack, Nathalie Meuwly, and Jessica Davila. "Negative Social Comparison on Facebook and Depressive Symptoms: Rumination as a Mechanism." Psychology of Popular Media Culture 2, no. 3 (2013): 161-70. doi:10.1037/a0033111.

Flett, Gordon L., Murray Stainton, Paul L. Hewitt, Simon B. Sherry, and Clarry H. Lay. "Procrastination Automatic Thoughts as a Personality Construct: An Analysis of the Procrastinatory Cognitions Inventory." Journal of Rational-Emotive \& Cognitive Behavior Therapy 30, no. 4 (2012): 233-36.

Flett, Gordon L., Kirk R. Blankstein, and Thomas R. Martin. "Procrastination, Negative Self-Evaluation, and Stress in Depression and Anxiety." In Procrastination and Task Avoidance, edited by Joseph R. Ferrari, Judith L. Johnson, and William G. McCown, 137-67. Boston, MA: Springer, 1995.

Forest, Amanda L., and Joanne Wood. "When Social Networking Is Not Working: Individuals with Low Self-Esteem Recognise but Do Not Reap the Benefits of Self-Disclosure on Facebook." SAGE Journals 23, no. 3 (2012): 295-302.

Fox, Jessie, and Jennifer Moreland. "The Dark Side of Social Networking Sites: An Exploration of the Relational and Psychological Stressors Associated with Facebook Use and Affordances." Computers in Human Behavior 45 (2015): 168-76. doi:10.1016/j.chb.2014.11.083.

GARTNER, "Gartner Survey Highlights Consumer Fatigue with Social Media," Your Story. Accessed February 24. https://yourstory.com/2011/08/gartner-survey-highlights-consumerfatigue-with-social-media.

Goffman, Erving. The Presentation of Self in Everyday Life. New York: Doubleday Anchor Books, 1959.

GolD, Brian T. "Enviousness and Its Relationship to Maladjustment and Psychopathology." Personality and Individual Differences 21, no. 3 (1996): 311-21. doi:10.1016/0191-8869 (96)00081-5.

Greenberg, Jeff, Sheldon Solomon, Tom Pyszczynski, Abram Rosenblatt, John Burling, Deborah Lyon, Linda Simon, and Elizabeth Pinel. "Why Do People Need Self-Esteem? Converging Evidence That Self-Esteem Serves and Anxiety-Buffering Function.” Journal of Personality and Social Psychology 63, no. 6 (1992): 913-22.

Guernsey, L. “A Cautionary Tale of Pediatricians, Parents, and Facebook.” February 19, 2014. http://www.slate.com/blogs/future_tense/2014/02/19/facebook_depression_scare_offers_a_ca utionary_tale_of_pediatricians_parents.html?via=gdpr-consent. 
HAFERKAMP, Nina, and Nicole C. KRÄMER. "Social Comparison 2.0: Examining the Effects of Online Profiles on Social-Networking Sites." Cyberpsychology, Behavior, and Social Networking 14, no. 5 (2011): 309-14. doi:10.1089/cyber.2010.0120.

Hinsch, Christian, and Kennon SHELdON. "The impact of frequent social Internet consumption: Increased procrastination and lower life satisfaction." Journal of Consumer Behaviour 12, no. 6 (2013): 496-505.

Hofmann, Stefan G., Anu AsnaAni, Imke J. Vonk, Alice T. SAwyer, and Angela Fang. "The Efficacy of Cognitive Behavioral Therapy: A Review of Meta-Analyses." Cognitive Therapy and Research 36, no. 5 (2012): 427-40.

Huang, Chiungjung. "Internet Use and Psychological Well-Being." Encyclopedia of Cyber Behavior, 302-14. doi:10.4018/978-1-4666-0315-8.ch026.

Hu, Xiaomeng, Andrew Kim, Nicolas SiweK, and Dawid Wilder. "The Facebook Paradox: Effects of Facebooking on Individuals' Social Relationships and Psychological Well-Being." Frontiers in Psychology 8 (2017): 87.

Jelenchick, Lauren A., Jens C. Eickhoff, and Megan A. Moreno. “'Facebook Depression?' Social Networking Site Use and Depression in Older Adolescents." Journal of Adolescent Health 52, no. 1 (2013): 128-30.

Johnston, Kevin, Maureen TANner, Nishant Lalla, and Dori KaWALSKI. "Social Capital: The Benefit of Facebook 'Friends'.” Behaviour \& Information Technology 32, no. 1 (2013): 24-36.

Jordan, Alexander, Benoit Monin, Carol S. Dweck, Benjamin J. LovetT, Oliver P. John, and James J. Gross. "Misery Has More Company than People Think: Underestimating the Prevalence of Others' Negative Emotions." Personality and Social Psychology Bulletin 37, no. 1 (2011): 120 .

JuDD, Terry. "Task Selection, Task Switching and Multitasking During Computer-Based Independent Study." Australasian Journal of Educational Technology 31, no. 2 (2015).

Kalpidou, Maria, Dan Costin, and Jessica Morris. "The Relationship Between Facebook and the Well-Being of Undergraduate College Students." Cyberpsychology \& Behavior 14, no. 4 (2015): 183-89.

KIM, Junghyun, and Jong-Eun Roselyn LEE. "The Facebook Paths to Happiness: Effects of the Number of Facebook Friends and Self-Presentation on Subjective Well-Being." Cyberpsychology, Behavior, and Social Networking 14, no. 6 (2011): 359-64. doi:10.1089/cyber.2010.0374.

KING, John L., and Kenneth L. KraEmer. "Computer-Based Models for Policy-Making: Uses and Impacts in the U.S. Federal Government." In Information Systems in the Political World, edited by Kim V. Andersen, 129-46. Amsterdam: IOS Press, 1995.

Koroleva, Ksenia, Oliver Günther, and Hanna Krasnova. “'Stop Spamming Me!' - Exploring Information Overload on Facebook.” Accessed June 2, 2018. https:/www.researchgate.net/ publication/220892528_\%27Stop_Spamming_Me\%27_-_Exploring_Information_Overload_ on_Facebook.

Krasnova, Hanna, Helena Eva Wenninger, Thomas Widjaja, and Peter Buxmann. "Envy on Facebook: A Hidden Threat to Users' Life Satisfaction?" Paper presented at 11th International Conference on Wirtschaftsinformatik. Leipzig, Germany 2013, February 27-March 1, 2013. https://www.researchgate.net/publication/256712913_Envy_on_Facebook_A_Hidden _Threat_to_Users'_Life_Satisfaction/link/559501ec08ae793d1379b742/download.

Krasnova, Hanna, Thomas Widjaja, Peter Buxmann, Helena E. Wenninger, and Izak Benbasat. "Research Note - Why Following Friends Can Hurt You: An Exploratory 
Investigation of the Effects of Envy on Social Networking Sites among College-Age Users." Information Systems Research 26, no. 3 (2015): 585-605. doi:10.1287/isre.2015.0588.

KraUt, Robert, and Moira BurKe. "Internet Use and Psychological Well-Being Effects of Activity and Audience." Communications of the ACM 58, no. 12 (2015): 94-100. doi:10.1145/2739043.

Kraut, Robert, Michael Patterson, Vicki Lundmark, Sara Kiesler, Tridas Mukophadhyay, and William ScherLIS. "Internet paradox: A social technology that reduces social involvement and psychological well-being?" American Psychologist 53, no. 9 (1998):101731. doi:10.1037//0003-066x.53.9.1017.

KwAN, Grace C. E., and Marko M. SKORIC. "Facebook bullying: An extension of battles in school." Computers in Human Behaviour 29, no. 1 (2013): 16-25.

Kwon, Min-Woo, Jonathan D'Angelo, and Douglas McLeod. "Facebook Use and Social Capital: To Bond, to Bridge, or to Escape." Bulletin of Science Technology \& Society 33, no. 1-2 (2013): 35-43.

Latané, Bibb, James H. Liu, Andrzej NowaK, Michael Bonevento, and Long Zheng. "Distance Matters: Physical Space and Social Impact." Personality and Social Psychology Bulletin 21, no. 8 (1995): 795-805. doi:10.1177/0146167295218002.

Lay, Clarry H., and Henri C. Schoumenburg. "Trait Procrastination, Time Management, and Academic Behavior.” Journal of Social Behavior and Personality 8, no. 4 (1993): 647-62.

Leary, Mark R., Ellen S. TAmbor, Sonja K. Terdal, and Deborah L. Downs. "Self-Esteem as an Interpersonal Monitor: The Sociometer Hypothesis." Journal of Personality and Social Psychology 68, no. 3 (1995): 518-30.

LeE, Eunsun, Yeo Jung Kim, and Jungsun AhN. "How do people use Facebook features to manage social capital?" Computers in Human Behavior 36 (2014): 440-45.

LEE, Sang Yup. "How do people compare themselves with others on social network sites? The case of Facebook." Computers in Human Behavior 32 (2014): 253-60. doi:10.1016/j.chb. 2013.12.009.

Masur, Philipp, Leonard Reinecke, Marc Ziegele, and Oliver Quiring. "The Interplay of Intrinsic Need Satisfaction and Facebook Specific Motives in Explaining Addictive Behavior on Facebook." Computers in Human Behavior 39 (2014): 376-86. doi:10.1016/j.chb.2014. 05.047 .

MAURYA, Ash. Running Lean: Iterate from Plan A to a Plan That Works. Sebastopol, CA: Oreilly \& Associates Inc., 2019.

MehdizAdeH, Soraya. "Self-Presentation 2.0: Narcissism and Self-Esteem on Facebook." Cyberpsychology, Behavior, and Social Networking 13, no. 4 (2010). doi:10.1089/cpb.2009.0257.

MeIER, Adrian, Leonard ReINECKe, and Chrisine E. Meltzer. “FFacebocrastination'? Predictors of using Facebook for procrastination and its effects on students' well-being." Computers in Human Behavior 64 (2016): 65-76. doi:10.1016/j.chb.2016.06.011.

Muise, Amy, Emily Christofides, and Serge Desmarais. "More Information than You Ever Wanted: Does Facebook Bring Out the Green-Eyed Monster of Jealousy?" CyberPsychology \& Behavior 12, no. 4 (2009): 441-44. doi:10.1089/cpb.2008.0263.

MYrick, Jessica G. "Emotion Regulation, Procrastination, and Watching Cat Videos Online: Who Watches Internet Cats, Why, and to What Effect?" Computers in Human Behavior 52 (2015): 168-76. doi:10.1016/j.chb.2015.06.001. 
Nadkarni, Ashwini, and Stefan G. Hofmann. "Why Do People Use Facebook?" Personality and Individual Differences 52, no. 3 (2012): 243-49.

NeSI, Jacqueline, and Mitchell J. Prinstein. "Using Social Media for Social Comparison and Feedback-Seeking: Gender and Popularity Moderate Associations with Depressive Symptoms." Journal of Abnormal Child Psychology 43, no. 8 (2015): 1427-38. doi:10.1007/s10802-0150020-0.

O'Keeffe, Gwen S., and Kathleen Clarke-Pearson. "The Impact of Social Media on Children, Adolescents, and Families." Pediatrics 127 (2011): 800-804. http://dx.doi.org/10.1542/peds. 2011-0054

PANTIC, Igor. "Online Social Networking and Mental Health." Cyberpsychology, Behavior, and Social Networking 17, no. 10 (2014): 652-57. doi:10.1089/cyber.2014.0070.

PERA, Aurel. "Psychopathological Processes Involved in Social Comparison, Depression, and Envy on Facebook.” Frontiers in Psychology 9, no. 22 (2018). doi:10.3389/fpsyg.2018.00022.

Pielot, Martin, Karen Church, and Rodrigo de Oliveira. "An In-Situ Study of Mobile Phone Notifications." In MobileHCI '14 Proceedings of the 16th international conference on Human-computer interaction with mobile devices \& services. New York, NY: ACM, 2014.

PISKORSKI, Mikołaj J. "Social Strategies That Work." Harvard Business Review 89, no. 11 (2011): 116-22.

PyszcZynski, Tom, and Jeff GreEnBerg. "Toward an Integration of Cognitive and Motivational Perspectives on Social Inference: A Biased Hypothesis-Testing Model. In Advances in experimental social psychology, edited by Leonard Berkowitz, 20:297-340. San Diego, CA: Academic Press, 1987.

Reinecke, Leonard, Tilo Hartmann, and Allision Eden. "The Guilty Couch Potato: The Role of Ego Depletion in Reducing Recovery Through Media Use.” Journal of Communication 64, no. 4 (2014): 569-89.

Rosen, Larry D., L. Mark CARrier, and Nancy A. Cheever. "Facebook and Texting Made Me Do It: Media-Induced Task-Switching While Studying." Computers in Human Behavior 29, no. 3 (2013): 948-58

RuSSEL, Bertrand. The Conquest of Happiness. London: Liveright, 1930.

Sagioglou, Christina, and Tobias Greitemeyer. "Facebooks Emotional Consequences: Why Facebook Causes a Decrease in Mood and Why People Still Use It." Computers in Human Behavior 35 (2014): 359-63. doi:10.1037/e514472015-239.

Schuur, Winneke A., Susanne E. Baumgartner, Sindy R. Sumter, and Patti M. Valkenburg. "The Consequences of Media Multitasking for Youth: A Review." Computers in Human Behavior 53 (2015): 204-15. doi:10.1016/j.chb.2015.06.035.

ShaKYA, Holly B., and Nicolas A. Christakis. "Association of Facebook Use with Compromised Well-Being: A Longitudinal Study." American Journal of Epidemiology 185, no. 3 (2017): 203-11. doi:10.1093/aje/kww189.

Sheldon, Kennon M., Neetu ABAD, and Christian Hinsch. "A Two-Process View of Facebook Use and Relatedness Need-Satisfaction: Disconnection Drives Use, and Connection Rewards it." Journal of Personality and Social Psychology 100, no. 4 (2011): 766-75.

SHORT, John. The social psychology of telecommunications. London: John Wiley \& Sons, 1976.

Smith, Richard H., and Sung Hee Kim. "Comprehending Envy." Psychological Bulletin 133, no. 1 (2007): 46-64. 
Steers, Mai-Ly N., Robert E. Wickham, and Linda K. Acitelli (2014). "Seeing Everyone Else's Highlight Reels: How Facebook Usage Is Linked to Depressive Symptoms." Journal of Social and Clinical Psychology 33, no. 8 (2014): 701-31.

Steinfield, Charles, Nicole B. Ellison, Chris Lampe, and Jessica Vitak. "Online Social Network Sites and the Concept of Social Capital." In Frontiers in New Media Research, edited by Francis L. F. Lee, Louis Leung, Jack Linchuan Qiu, Donna S.C. Chu, 115-31. New York: Routledge, 2012.

Steinfield, Charles, Nicole B. Ellison, and Chris LAmpe. "Social Capital, Self-Esteem, And Use Of Online Social Network Sites: A Longitudinal Analysis." Journal of Applied Developmental Psychology 29, no. 6 (2008): 434-45. doi:10.1016/j.appdev.2008.07.002.

StÖBer, Joachim, and Jutta Joormann. "Worry, Procrastination, and Perfectionism: Differentiating Amount of Worry, Pathological Worry, Anxiety, and Depression." Cognitive Therapy and Research 25, no. 1 (2001): 49-60. doi:10.1023/A:1026474715384.

Stothart, Cary, Ainsley Mitchum, and Courtney Yehnert. "The Attentional Cost of Receiving a Cell Phone Notification." Journal of Experimental Psychology Human Perception \& Performance 41, no. 4 (2015): 893-97. doi:10.1037/xhp0000100.

Stutzman, Frederic, Jessica Vitak, Nicole B. Ellison, Rebecca Gray, and Cliff Lampe. "Privacy in Interaction: Exploring Disclosure and Social Capital in Facebook." Paper presented at the Sixth AAAI Conference on Weblogs and Social Media, Dublin, Ireland, June 4-7, 2012. https://www.aaai.org/ocs/index.php/ICWSM/ICWSM12/paper/view/4666/5000.

Sutcliffe, Paul, Steven Martin, Jackie Sturt, John Powell, Frances Griffiths, Ann AdAms, and Jeremy DALE. "Systematic Review of Communication Technologies to Promote Access and Engagement of Young People With Diabetes Into Healthcare." BMC Endocrine Disorders 11, no. 1 (2011). doi:10.1186/1472-6823-11-1.

Valenzuela, Sebastian, Namsu PARK, and Kerk F. Kee. "Is There Social Capital in a Social Network Site? Facebook Use and College Students Life Satisfaction, Trust, and Participation." Journal of Computer-Mediated Communication 14, no. 4 (2009): 875-901. doi:10.1111 /j.1083-6101.2009.01474.x.

Valkenburg, Patti M., and Jochen J. Peter. "Social Consequences of The Internet For Adolescents." Current Directions in Psychological Science 18, no. 1 (2009): 1-5. doi:10. 1111/j.1467-8721.2009.01595.x.

Valkenburg, Patti M., Jochen J. Peter. "The Effects of Instant Messaging on the Quality of Adolescents' Existing Friendships: A Longitudinal Study. Journal of Communication 59 (2009): 79-97. https://doi.org/10.1111/j.1460-2466.2008.01405.x.

Verduyn, Philippe, David S. Lee, Jiyoung Park, Holly Shablack, Ariana Orvell, Joseph BAYER, Oscar YBARRA, John JONIDES, and Ethan Kross. "Passive Facebook Usage Undermines Affective Well-Being: Experimental and Longitudinal Evidence." Journal of Experimental Psychology: General 144, no. 2 (2015): 480-88.

VITAK, Jessica. "The impact of context collapse and privacy on social network site disclosures." Journal of Broadcasting \& Electronic Media 56, no. (212): 451-70.

Vogel, Erin. A., Jason P. Rose, Lindsay Roberts, and Katheryn Eckles. "Social Media, Social Comparison, And Self-Esteem." Psychology of Popular Media Culture 3, no. 4 (2014). doi:10.1037/e512142015-699.

Vogel, Erin A., Jason P. Rose, Bradley M. OKdIE, Katheryn ECKLES, and Brittany Franz. "Who Compares and Despairs? The Effect of Social Comparison Orientation On Social Media Use 
and Its Outcomes.” Personality and Individual Differences 86 (2015): 249-56. doi:10.1016/ j.paid.2015.06.026.

WAllströM, Peter. Evaluation of Forecasting Techniques and Forecast Errors with Focus on Intermittent Demand. Luleå, Sweden: Luleå University of Technology, 2009. https://www. diva-portal.org/smash/get/diva2:990519/FULLTEXT01.pdf.

Wigtil, Cliffton J., and Gregg R. HenriQues. "The Relationship Between Intelligence and Psychological Well-Being in Incoming College Students." Psychology of Well-Being 5, no. 1 (2015): 1-19. doi:10.1186/s13612-015-0029-8.

Wilson, Robert E., Samuel D. Gosling, and Lindsay T. Graham. "A Review of Facebook Research in the Social Sciences." SAGE Journals 7, no. 3 (2012): 203-20.

XU, Shan, Zheng J. WANG, and David PraBu. "Media multitasking and well-being of university students." Computers in Human Behavior 55 (2016): 242-50. doi:10.1016/j.chb.2015.08.040.

ZiLlmanN, Dolf. "Mood management through communication choices." American Behavioral Scientist 31, no. 3 (1988): 327-41.

\section{HOW DOES FACEBOOK MAKE US UNHAPPY? A RESEARCH REVIEW}

Summary

Research shows that Facebook use may cause detrimental effects on users' well-being. However, mixed results are often found regarding the relationship between Facebook use and depressive symptoms due to different concepts of well-being used by researchers (raising difficulty in comparing the findings) and Facebooks multi-purpose nature where measuring "general use" is likely an oversimplification resulting in imprecise interpretation regarding the nature of this association. The aim of this research review is to introduce contemporary findings on the link between Facebook use and depression. Consequently, the effects of nuanced and potentially highly negative well-being issues diverging from Facebook use are discussed. Special attention is paid to envy and social comparison on Facebook. The results of the research review indicate that negative consequences of using Facebook include but are not limited to: negative social comparison, jealousy, envy, surveillance behaviors, social isolation, procrastination, increasing social tension and a state of fatigue resulting from "social overload" and that these consequences can lower users both affective and psychological well-being, facilitate depressive symptoms and in some cases cause depression.

Key words: Facebook; well-being; depression; envy; social comparison.

\section{W JAKI SPOSÓB FACEBOOK CZYNI NAS NIESZCZĘŚLIWYMI? PRZEGLĄD BADAŃ}

\section{Streszczenie}

Badania pokazują, że korzystanie z Facebooka może mieć szkodliwy wpływ na samopoczucie użytkowników. Często pojawiające się dane wskazują na związek między korzystaniem z Facebooka a objawami depresyjnymi, choć ze względu na różne koncepcje dobrostanu stosowane przez badaczy występuje podstawowa trudność w porównywaniu wyników. Celem tego przeglą- 
du badań jest przedstawienie współczesnych ustaleń dotyczących związku między korzystaniem z Facebooka a depresją. W związku z tym omawiane są skutki zniuansowanych i potencjalnie wysoce negatywnych problemów związanych z dobrostanem odbiegających od korzystania z Facebooka. Szczególną uwagę przywiązuje się do zazdrości i kontaktów towarzyskich na Facebooku. Wyniki przeglądu badań wskazują, że negatywne konsekwencje korzystania z Facebooka obejmują między innymi: negatywne porównanie społeczne, zazdrość, zachowania inwigilacyjne, izolację społeczną, kunktatorstwo, rosnące napięcie społeczne i stan zmęczenia wynikający z przeciążenia. Konsekwencje te mogą obniżyć zarówno dobrostan afektywny, jak i psychiczny, ułatwić objawy depresyjne, a w niektórych przypadkach powodować depresję.

Słowa kluczowe: Facebook; dobre samopoczucie; depresja; zazdrość; porównania społeczne. 